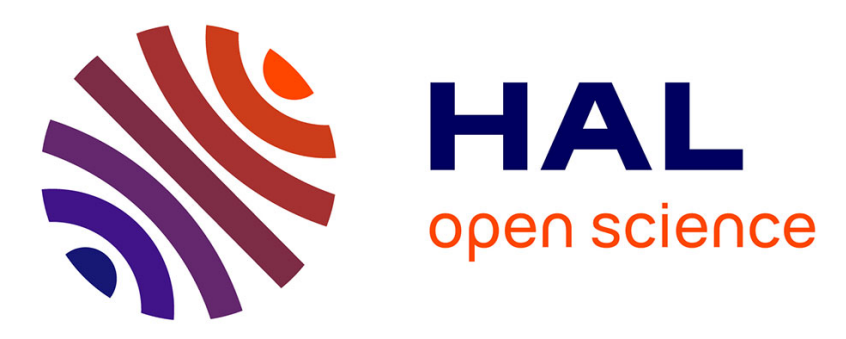

\title{
Laser-induced fluorescence and photothermal spectroscopies for monitoring relaxation processes in photoexcited species
}

A. Chartier, J. Georges

\section{- To cite this version:}

A. Chartier, J. Georges. Laser-induced fluorescence and photothermal spectroscopies for monitoring relaxation processes in photoexcited species. Journal de Physique IV Proceedings, 1994, 04 (C4), pp.C4-699-C4-699. 10.1051/jp4:19944184 . jpa-00252644

HAL Id: jpa-00252644

https://hal.science/jpa-00252644

Submitted on 1 Jan 1994

HAL is a multi-disciplinary open access archive for the deposit and dissemination of scientific research documents, whether they are published or not. The documents may come from teaching and research institutions in France or abroad, or from public or private research centers.
L'archive ouverte pluridisciplinaire HAL, est destinée au dépôt et à la diffusion de documents scientifiques de niveau recherche, publiés ou non, émanant des établissements d'enseignement et de recherche français ou étrangers, des laboratoires publics ou privés. 


\section{Laser-induced fluorescence and photothermal spectroscopies for monitoring relaxation processes in photoexcited species}

\section{A. CHARTIER and J. GEORGES}

Laboratoire des Sciences Analytiques, UA 435 du CNRS, Bât. 308, Université Claude Bernard Lyon I, 69622 Villeurbanne cedex, France

Besides the applications of photothermal spectroscopy for measuring weak absorptions in analytical chemistry, the method can provide calorimetric information and is complementary to fluorescence and conventional absorption methods. Pulsed laser sources can be used to determine not only radiative and non-radiative quantum yields but also decay kinetics of excited molecules in solution. Time-resolved photothermal spectrometry is able to give information on heat evolution depending on whether the radiationless deactivation processes are fast or slow with respect to the acoustic transit time in the medium [1]. For processes that are slower than the acoustic transit time, the thermal lens signal exhibits a slow rising component superimposed on the fast component [2].

Example processes that can be monitored simultaneously by fluorescence and thermal lens spectrometries include energy transfer studies in lanthanide chelates used to improve the fluorimetric determination of lanthanide ions. Following ligand absorption and energy transfer from the ligand to the ion, lanthanide-sensitized fluorescence results in both a strong increase in ion emission and the appearance of a slow rising component on the time-resolved thermal lens curve [3]. In the case of europium, it is shown that both events occur over the same time scale (microsecond domain) and are related to radiative and non-radiative relaxation of the long-lived ${ }^{5} \mathrm{D}_{\mathrm{o}}$ state of $\mathrm{Eu}^{3+}$. Relevant information can thus be obtained about the competitive photophysical processes occuring in such chelates. For example, comparisons of fast and slow components of the thermal lens signal and of the overall signal amplitude with that of a reference absorber should theoretically allow the determination of intramolecular energy transfer and ion luminescence efficiencies.

[1] D.R. Siebert, F.R. Grabiner and G.W. Flynn, J. Chem. Phys. 60, 1564 (1974).

[2] J. Georges, Spectrochim. Acta Rev. 15, 39 (1993).

[3] J. Georges and J.M. Mermet, Spectrochim. Acta 49A, 397 (1993). 